\title{
The Effect of Convenience and Self-Efficacy Factors on the Consumption Experience, Mediated by Emotion
}

\author{
Darra Pradita Hidayat ${ }^{1}$ and Hardika Widi Satria ${ }^{2}$ \\ ${ }^{1}$ Management Studies Program, Faculty of Economics and Business, Perbanas Institute, Indonesia \\ ${ }^{2}$ Social and Humanities Department, Communication - Advertising Studies, \\ Vocational Education Program, Universitas Indonesia \\ *E-mail: darrapraditahidayat@gmail.com
}

\begin{abstract}
This research aims to analyze the effect of convenience and self-efficacy on the consumption experience, including the mediating effect of emotion. Data used in this study are primary data obtained by questionnaires of 300 respondents. The sample collection techniques use purposive sampling. Validity and reliability are used for the instrument tests and structural equation modelling (SEM) is used for hypothesis testing. The result shows that there are positive effects of convenience and self-efficacy on the consumption experience, and emotion can have a positive mediation effect.
\end{abstract}

Keywords: convenience, self-efficacy, emotion, consumption experience, m-commerce, utilitarian, hedonic

\section{Introduction}

Mobile commerce (m-commerce) is a relevant service. The concept of e-commerce is quite developed among information technology (IT) innovations (Kleijnen et al., 2007; Ko et al., 2009). E-commerce benefits the producer, the consumer, and the retailer. Mobile commerce is a part of e-commerce; it describes the ecommerce activities that are controlled in full or in part on wireless states such as: mobile phones, PDAs, tablets, and notebooks,. (Turban, Efraim, King, Lee, and Viehland, 2004). The presence of mobile networks, the increased use of wireless devices, and the security of mobile payments have resulted in increased use of handheld devices in utilizing $\mathrm{m}$-commerce. In m-commerce, users easily transact online without having to go to a brick and mortar store. Consumers enjoy the ease and services provided by companies with m-commerce services (Rainer and Cegielski, 2007). Today's shopper interacts through the virtual world with sellers that aim to understand and meet their needs easily, quickly and efficiently.

Consumers shopping directly or online perceive benefits in product quality and prices that are not only determined by a utilitarian approach to satisfy basic needs but also through a hedonistic approach that is a lifestyle that considers that shopping not only because the fulfillment of the needs of every consumer. However, more because of factors that can bring pleasure, satisfaction, prestige that can be provided by service providers through the creation of convenience in shopping using intermediary media such as gadgets in operationalizing online shopping activities. Competitive pressure means that practitioners studying consumer behavior need effective methods to help analyze consumer preferences and choices in using m-commerce services.

Previous research on consumer behavior suggests that rational and utilitarian decisions are very important factors in m-commerce. Characteristics of m-commerce, such as system quality, facilities, trust, and mobile comfort have been adopted in m-commerce research (Choi et al., 2008; Kleijnen et al., 2004; Lu et al., 2008). Recently, studies have begun exploring hedonistic factors, such as visual aesthetics and fun that affect the users' experience (Ko et al., 2009; Li and Yeh, 2010; Turel et al., 2010). Utilitarian factors are attributes related to utilitarian consumer considerations and hedonic factors refer to elements that satisfy the pleasure or wishes of consumers (O'Brien, 2010). Both factors combine in the emergence of a philosophy that places great emphasis on the consumer's experience of seeking pleasure and satisfaction (Holbrook and Hirschman, 1982b, Davis, 2010). In contrast to utilitarian consumption, the basis of hedonic consumption in the development of services or consumption processes, often followed by significant emotional changes in behavior (Hoffman and Novak, 1996, Holbrook and Hirschman, 1982b). Customers can experience a fun experience through mobile communication as a form of individual expression. Therefore, it is important to understand m-commerce from an experience perspective, which highlights the importance of emotion in the user experience.

The purpose of this study is to explore the role of emotion in the consumer consumption experience in the context of m-commerce from an experiential point of view. This study looks at the experience aspect of $\mathrm{m}$ commerce regardless of consumption type. Understanding customer considerations can guide managers in developing strategies for m-commerce. This study is composed as follows. Next is a brief overview of previous research related to $\mathrm{m}$-commerce that provides a theoretical foundation for the research. The next section 
presents the research model and proposes a hypothesis to be tested to know and interpret the behavior and attitudes of consumers in using m-commerce services, determine their consumption type, and understand the role of consumer experience on the use of m-commerce. The fourth section presents the Results and Discussion and the last section is the Conclusion and Managerial Implications.

\section{Literature Review}

\subsection{Convenience}

Convenience can be interpreted as the comfort of a person in using a tool or an object. In m-commerce, convenience is measured through consumer perceptions of the effort and time involved in utilizing an $\mathrm{m}$ commerce device or application (Berry et al., 2002). Comfort is one of the most important factors in the success of m-commerce (Kim et al., 2010; Xu and Gutierrez, 2006). Convenient delivery of customer satisfaction and value is a must in a dynamic competitive service. Failure to provide comfort can result in costly customer losses and future revenue flows to compensate for the losses (Reichheld and Teal, 1996).

Technological advances have led consumers' desires to conduct business more easily (Berry, 1979; Gross, 1987; Seiders et al., 2000). To satisfy consumers' desire for convenience (Lovelock, 2001; Dabholkar et al., 2003) and to minimize potential customer losses (Keaveney, 1995), service providers use methods such as Internet commerce, live chats, and mobile telecommunication services. Increasing convenience for consumers means an organization also must make a significant investment in offering products and services.

\subsection{Self-efficacy}

The concept of self-efficacy was first proposed by Bandura. Self-efficacy refers to perceptions of an individual's ability to organize and implement actions to display certain skills (Bandura, 1986). Baron and Byrne (2000) suggest that self-efficacy is an individual's judgment of his ability or competence to perform a task, achieve a goal, or produce something. In addition, Schultz (1994) defines self-efficacy as one's sense of adequacy, efficiency, and the ability to cope with life.

Self-efficacy affects everyone in choosing activities. Consumers with low self-efficacy may avoid very difficult services, especially services that have complex requirements. Conversely, consumers with high selfefficacy are more confident and want to understand and seek services they fit their needs. Bandura adds that self-efficacy lies at the center of cognitive social theory, which emphasizes observational learning and social experience in personality development. Users with higher self-efficacy tend to experience more types of communication media and functions.

\subsection{Emotion}

Emotion is the heart of the user experience; it affects how users plan to interact with products, how they perceive them, and the outcomes of their interactions (Forlizzi and Battarbee, 2004). Researchers can interpret users' experience and emotions through interaction (Forlizzi and Battarbee, 2004). Emotions refer to emotional responses that give rise to attitude during product use (Gupta and Kim, 2007). Consumers' emotional responses (such as pleasure) may affect their intention to use a product. Evidence shows that emotion has an important role in adopting the use of technology. Given the network externalities, consumers' perceived enjoyment is essential to their adopting technology (Dickinger et al., 2008).

\subsection{Consumption Experience}

To understand consumer experience, we must realize that consumers are trying to achieve some goals by buying and using certain products or services (Ratneshwar et al., 2000). Jones (1999) points out that many consumers have certain tasks in mind when going shopping. Verhoef et al., (2009) show that customer experience is made not only by elements that the retailer can control (e.g. face-to-face interactions, price variations) but also from elements outside the retailer's control (e.g. other people, choice of shopping destination). They also suggest that goals affect how consumers understand the environment and its individual elements, their spending behaviors, and their satisfaction with the shopping experience. Their goals have an important role in planning and understanding the customer experience in retail context.

The experience of consuming can be felt when consumers first use products and services, so it can be seen whether the visible satisfaction from consumers or not to the products and services used. In the post-purchase period, consumers can assess their own satisfaction, which may affect their decisions in the future. Codeluppi (2000) considers that pleasure comes from experience, not from purchasing a product or service. Consumption experience 
can be discovered from consumers' reactions after using a product (Holbrook and Hirschman, 1982b). M-commerce faces different characteristics with each user, so its approach must consider the form of interaction.

\subsection{Hypothesis}

Several studies have proved that convenience and emotion have a positive influence on each other (Min Li et al., 2011). Purchase convenience is increasingly important to customers. This phenomenon has driven the development of convenience in goods and services that motivate consumers to make purchasing decisions (Gupta and Kim, 2007). The continuous increase in consumer demand for convenience has been attributed to socio-economic changes, technological advances, more competitive business environments, and opportunity costs (Berry et al., 2002). This leads to the first hypothesis.

H1: Convenience has a positive influence on emotion in m-commerce use.

Self-efficacy is believed to affect a person's mind-set and emotional reactions, especially in regulating emotions when experiencing a threatening or difficult situation (Bandura, 1997). Users with high self-efficacy tend use more types and functions of a communication medium; whereas, low self-efficacy users can be restricted in their communication media. User experience in an m-commerce service tends to be more fun and lead to a sense of satisfaction. Empirical evidence of a causal relationship between self-efficacy and behavioral intentions, mediated by utilitarian perceptions (perception of ease of use), has been demonstrated in the context of wireless financial products (Luarn and Lin, 2005). This leads to the second hypothesis.

\section{H2: Self-efficacy has a positive effect on emotion in m-commerce use.}

Emotion is the heart of the user experience, and affects how consumers plan to interact with products, how they perceive them, and the outcomes of their interactions (Forlizzi and Battarbee, 2004). Researchers interpret users' experience and emotions through interaction (Forlizzi and Battarbee, 2004). Communication makes an experience enjoyable when consumers start to express their feelings and moods in different ways. In terms of social orientation, user consumption can bring a pleasant experience and play an important role, perhaps through the adoption of trends and fashions (Haytko and Baker, 2004). People tend to engage in recurring behaviors from their positive past experiences; consequently, if users have a positive experience with m-commerce services, they keep using the service. Evidence suggests that emotions have an important role in the adoption of technology (Dickinger et al., 2008). This leads to the third hypothesis.

H3: Emotion has a positive influence on consumption experience

The conceptual framework in this research can be seen in detail in Figure 1 below.

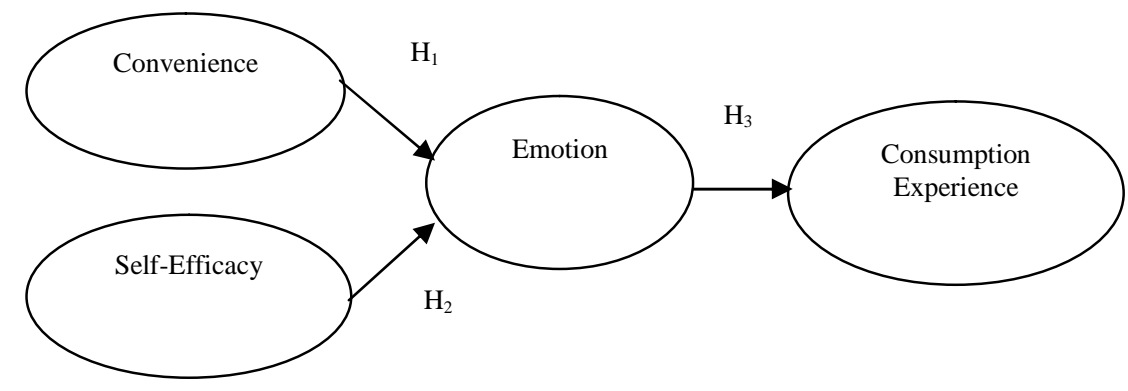

Fig. 1. Conceptual Framework

\section{Methodology}

\subsection{Research Approach and Design (Quantitative)}

This research refers to Min and Dong (2011). The design of this study is a survey that aims to test the hypothesis about the effect of convenience and self-efficacy on consumption experience, mediated through emotion. The research method is using quantitative structural equation model (SEM) method that focuses on 
hypothesis testing by using measured data to draw a conclusion. SEM is a statistical technique that allows testing of a series of relations simultaneously. The relationship is built on one or more independent variables. This research is cross sectional. The analytical unit is an individual who has experienced using $\mathrm{m}$-commerce as a medium of information and transactions in Jakarta, Indonesia. Data come from questionnaire responses. Users are asked about their experience in using m-commerce in daily life and whether or not they are satisfied in using m-commerce.

\subsection{Variables and Measurements}

Table 1 shows the variables used in this study. It contains a matrix of variables and measurements, namely; (1) the independent variables of convenience and self-efficacy, (2) the dependent variable of consumption experience, and (3) the intervening variable of emotion.

Table 1. Matrix Variables and Measurements

\begin{tabular}{|c|c|c|}
\hline Variable & Items & Source \\
\hline Convenience & $\begin{array}{l}\text { 1. M-commerce services can provide comfort for not wasting } \\
\text { much of my time. } \\
\text { 2. M-commerce services can provide convenience because it } \\
\text { can provide ease in accessing what I want. } \\
\text { 3. M-commerce services can provide convenience because it } \\
\text { can be used anytime. } \\
\text { 4. M-commerce services can provide convenience because it } \\
\text { can be used anywhere. } \\
\text { 5. M-commerce services can provide comfort because the phone } \\
\text { is always there near me. }\end{array}$ & $\begin{array}{l}\text { Gupta and Kim, } \\
2007 \text {; Kim et al., } \\
2010\end{array}$ \\
\hline Self-efficacy & $\begin{array}{l}\text { 1. I can do m-commerce service successfully if I am expert in } \\
\text { using mobile phone to meet my needs. } \\
\text { 2. I can do m-commerce services successfully if I feel confident } \\
\text { in using the phone to meet my needs. } \\
\text { 3. I can do m-commerce services successfully if I am able to } \\
\text { overcome the instructions given in the use of m-commerce on } \\
\text { my phone. } \\
\text { 4. I can do m-commerce service successfully if I have used the } \\
\text { same system before. }\end{array}$ & $\begin{array}{l}\text { Hung and Chang, } \\
\text { 2005; Luarn and } \\
\text { Lin, } 2005\end{array}$ \\
\hline Emotion & $\begin{array}{l}\text { 1. In using m-commerce services, I feel: (very unhappy-very } \\
\text { happy) } \\
2 \text {. In using m-commerce services, I feel: (very dissatisfied-very } \\
\text { satisfied) } \\
3 \text {. In using m-commerce services, I feel access: (very unfree- } \\
\text { very liberal) } \\
4 \text {. In using m-commerce services, I use it with: (full awareness- } \\
\text { under influence) } \\
5 \text {. In using m-commerce services, I feel: (very unenthusiastic- } \\
\text { very enthusiastic) }\end{array}$ & $\begin{array}{l}\text { Donovan } \\
\text { Rossiter, } \\
\text { Eroglu et al., 2001; } \\
\text { Eroglu et al., } 2003 \text {; } \\
\text { Voss et al., } 2003\end{array}$ \\
\hline $\begin{array}{l}\text { Consumption } \\
\text { experience }\end{array}$ & $\begin{array}{l}\text { 1. For the future, I will spend a lot of time in m-commerce } \\
\text { services. } \\
\text { 2. For the future, I will invest more money to keep getting m- } \\
\text { commerce services. } \\
\text { 3. For the future, I will still use m-commerce. } \\
\text { 4. For the future, I will use m-commerce more often. }\end{array}$ & $\begin{array}{l}\text { Holbrook and } \\
\text { Hirschman, } 1982\end{array}$ \\
\hline
\end{tabular}

\subsection{Research Population}

The sample is 300 respondents in Jakarta who have used m-commerce. Non-probability sampling was used, which is a subjective procedure in which samples are not selected randomly, but rather are selected with certain criteria. In this case, the probability of selecting the elements of the population cannot be determined because each element of the population does not have the same chance of being selected as a sample member. The sampling technique used is purposive sampling or judgmental sampling. Sampling based on consideration is a 
form of selection or withdrawal based on certain criteria (Hermawan, 2009). The respective characteristics needed to be part of the sample and answer the questionnaire are as follows:

1. Respondents are people who have used m-commerce as a means of buying transactions products or services.

2. Respondents' must be older than 17 years

3. Respondents have gadgets that can be used as a means of wireless transactions.

\subsection{Validity Test}

A validity test is conducted to find out whether all of the research (indicator) variable statements proposed are valid. Validity refers to the extent to which the measurement scale is capable of measuring what should be measured (Nazir, 2003). Understanding valid in the validity test is if the item statement submitted to measure the research variables is declared eligible to be a statement in measuring research variables. The analysis tool for the validity test is a Pearson correlation, with the help of SPSS 11.5 software. The basis of a decision-making validity test is as follows:

-If the p-value is equal to or greater than 0.05 then the item statement is valid

-If the p-value is less and 0.05 then item statement is invalid

\subsection{Reliability Test}

According Sugiono (2005), reliability in a series of measurements or a series of measuring tools is consistent with repeated measurements. The reliability test of each construct used in this study used the Cronbach's alpha method with the help of SPSS 11.5 software. Cronbach's alpha is a reliability coefficient that shows how well items in a set are positively correlated with each other. An acceptable Cronbach's alpha coefficient is more than 0.60 (Nazir, 2003). The decision-making reliability test can be summed up as follows:

-If the Cronbach's alpha coefficient is equal to or greater than 0.60 , then the statement in the questionnaire is worth using (the construct is reliable)

-If the Cronbach's alpha coefficient is less than 0.60, then the statement in the questionnaire is not worth using (the construct is unreliable).

Table 2. Shows a matrix of the Pearson correlation and Chronbach's alpha tests of validity and reliability.

Table 2. Matrix of Correlation and Reliability

\begin{tabular}{cccc}
\hline Constructs and indicators & Pearson Correlation & Cronbad'salpha & Decision \\
\hline Convenience & & 0,8755 & Reliable \\
$c 1$ & 0,814 & & Valid \\
$c 2$ & 0,837 & & Valid \\
$c 3$ & 0,842 & & Valid \\
$c 4$ & 0,825 & & Valid \\
$c 5$ & 0,782 & & Valid \\
Self Efficacy & & 0,7936 & Reliable \\
sel & 0,788 & & Valid
\end{tabular}




\begin{tabular}{cccc}
\hline Constructs and indicators & Pearson Correlation & Cronbach's alpha & Decision \\
\hline$s e 2$ & 0,834 & & Valid \\
$s e 3$ & 0,775 & & Valid \\
se4 & 0.749 & & Valid \\
& & 0,8795 & \\
Emotion & & & Reliable \\
em1 & 0,843 & Valid \\
em2 & 0,852 & Valid \\
em3 & 0,784 & & Valid \\
em4 & 0,830 & & Valid \\
em5 & 0,800 & & Valid \\
& & 0,8514 & Reliable \\
Consumption Experience & & & Valid \\
cel & 0,833 & & Valid \\
$c e 2$ & 0,837 & & Valid \\
$c e 3$ & 0,801 & & Valid \\
$c e 4$ & 0,860 & & \\
\hline
\end{tabular}

Based on the validity test in Table 2, all variables are declared valid, because the value of the Pearson correlation on each item statement has a strong influence on the variables tested indicates the above statement items are valid. In addition, for the value of Cronbach's Alpha on each variable has a value> 0.6 and it can be said reliable. So, from each variable Cronbach's alpha can be concluded reliable.

\subsection{Data Analysis Method}

SEM was used to analyses the relationship or influence between the dependent variable and the independent variable. Before conducting the overall hypothesis test (the overall fit models), we first measure the conformity level that the model can describe all the goodness-of-fit relationships. The types of goodness-of-fit measurements according to Hair, Anderson Tatham and Black (1998) are; (1) absolute fit measures, (2) incremental fit measures, (3) parsimonious fit measures. Researchers recommend using one or more of each type of measurement, but the main requirement is to look at the p-value. If the p-value is greater than the alpha value, the measurement of goodness of fit shows no significant meaning that the measurement is fit. If the pvalue is smaller than the alpha value, the measurement of goodness of fit shows significant meaning that the measurement is not fit and other measurements should be taken. Goodness of fit used in this research are as follows:

\section{Absolute fit measure}

It measures the overall fit model (both structural models and measurement models simultaneously) by following these criteria:

\section{a. The Like Hood-Ratio Chi Square Statistic}

The minimum acceptable significant level is expected to be small, at about 0.05 to 1 at the chi-square level of measurement. The researchers looked for non-significant differences due to these tests between actual and predictive matrices. However, if the outcome is less than 0.5 or more than 1 , then the test shows there is not goodness of fit. Chi-square measurements depend heavily on the number of samples, so some researchers recommend combining this study with other measures (Hair, Anderson, and Black, 1998).

\section{b. Goodness-of-Fit-Index (GFI)}

The higher the value of GFI, the better fit in a research model. There is no value that can be used as reference, but some researchers recommend a GFI of 0.90 or more.

\section{c. The Root Mean Square Error of Approximation (RMSEA)}

This is an index that can be used to compensate for chi-square statistics in large samples. The RMSEA value shows the goodness of fit that can be expected if the model is estimated from the population. RMSEA can be used when the chi-square value is significant. The value needed for the RMSEA to fit is less than 0.10 (Hair, Anderson Tatham and Black, 1998). 


\section{Incremental Fit Measures}

The size to compare the proposed model with other models specified by the researchers following these criteria:
a. Adjust-goodness-of-fit-index (AGFI)

It is recommended that AGFI acceptance rate is greater or equal to 0.90 .

b. Tucker-Lewis Index (TLI)

The recommended value should be greater than 0.90 .

c. Normed-Fit-Index (NFI)

The recommended value should be greater than 0.90 .

d. Comparative Fit Index (CFI)

\section{Parsimonious Fit Measures}

To adjust the fit measurements to be comparable between models with different coefficients. The criteria can be set by looking at normed chi-square values (CMIN / DF). The recommended value is lower limit of 1 or upper limit 5.

The method used in this study to test the hypothesis is analyzing the data with a confidence level of $95 \%$ ( $\alpha$ $=0.05)$.

Table 3. Goodness of Fit Model Testing

\begin{tabular}{|c|c|c|c|c|}
\hline Type of Measurement & Measurement & Value & Recommended limits & Conclusion \\
\hline \multirow[t]{3}{*}{ Absolute Fit Measures } & Chi square & 701.943 & $X^{2}$ hit $<x^{2}$ tabel $(d f=295)$ & Poor fit \\
\hline & p-value & 0.000 & $\geq 0.05$ & Poor fit \\
\hline & RMSEA & 0.069 & $\leq 0.10$ & Goodness of fit \\
\hline \multirow[t]{3}{*}{ Incremental Fit Measures } & $T L I$ & 0.867 & $\geq 0.90$ & Marginal Fit \\
\hline & $N F I$ & 0.831 & $\geq 0.90$ & Marginal Fit \\
\hline & CFI & 0.891 & $\geq 0.90$ & Marginal Fit \\
\hline Normed chi square & & 2.437 & Lower limit 1, upper limit 5. & Goodness of fit \\
\hline
\end{tabular}

Based on Table 3, on the absolute fit measuring the main requirement of chi square value is not fulfilled; demonstrated by the chi square value of 701,943 with p-value 0.000 (below 0,05) so it can be concluded that this model has a poor fit. SEM is very sensitive to the number of samples used in a study, meaning that greater number of respondents has a better SEM outcome; however, on the other hand, it can cause the value of CMIN to get bigger so that Ho is accepted in the test of goodness of fit. Therefore, we can see the RMSEA value of 0.069 (less than 0.10). Criteria based on incremental fit measures can be seen from NFI values of $0.831(\geq 0.90$ or near 1), TLI of 0.867 ( $\geq 0.90$ or near 1) CFI of 0.891 ( $\geq 0.90$ or near 1 ). Thus, the value of NFI, TLI, and CFI do not mean poor fit, but rather marginal fit, because the value is still tolerable and is in the grey area. Criteria based on a parsimonious fit measure by looking at the value of normed chi square of 2,437 (fulfilling the lower boundary 1 and upper limit 5). So, it can be concluded that this model is still declared marginally feasible to be used as a tool in confirming the theory that has been built based on existing observation data or can be said this model goodness of fit.

\section{Results and Discussion}

\subsection{Descriptive Statistics}

Based on the results in Table 4, convenience has an average value of 3.9567, which means that, overall, consumers identify a high enough level of convenience on the use of m-commerce. The average value of the standard deviation of 0.88548 indicates that respondents' answers varied. Self-efficacy has an average value of 3.5333, which means that respondents consider themselves successful in using m-commerce services. The 
average value of the standard deviation is 0.86296 , which means the respondents' answers varied. Emotion produced an average score of 3.6433, which means that ]overall, in the eyes of the respondent, emotion is quite important and influential in the continuity of $\mathrm{m}$-commerce use. The average value of the standard deviation is 0.68142 , which means the answers of all the respondents varied. Consumption experience has an average value of 3.4567 which means that, overall, respondents have enough experience in using m-commerce services. The average value of the standard deviation of 0.86252 means the answer varies.

Table 4. Descriptive Statistics of Convenience, Self-Efficacy, Emotion, Consumption Experience

\begin{tabular}{|c|c|c|}
\hline Variable & Mean & $\begin{array}{c}\text { Standard } \\
\text { Deviation }\end{array}$ \\
\hline Convenience & 3.9567 & 0.88548 \\
\hline Self-Efficacy & 3.5333 & 0.86296 \\
\hline Emotion & 3.6433 & 0.68142 \\
\hline $\begin{array}{c}\text { Consumption } \\
\text { Experience }\end{array}$ & 3.4567 & 0.86252 \\
\hline
\end{tabular}

\subsection{Hypothesis Testing}

The basis of decision-making hypothesis test is by comparing the p-value with a significant level of 5\% (alpha $=0,05$ ). If $\mathrm{p}$-value < alpha 0.05 then the null hypothesis (Ho) is rejected and If $\mathrm{p}$-value $>$ alpha is 0.05 then the null hypothesis (Ho) fails to be rejected as seen in Table 5.

Table 5. Hypotheses Testing Results

\begin{tabular}{lccc}
\hline Hypothesized path & $\begin{array}{c}\text { Standardized path } \\
\text { coefficient }\end{array}$ & p-value & Decision \\
\hline $\mathrm{H} 1:$ Convenience $\rightarrow$ Emotion & 0.205 & 0.000 & H1 Supported \\
$\mathrm{H} 2:$ Self-Efficacy $\rightarrow$ Emotion & 0.427 & 0.000 & H2 Supported \\
$\mathrm{H} 3:$ Emotion $\rightarrow$ Consumption & 0.959 & 0.000 & H3 Supported \\
Experience & &
\end{tabular}

\section{Hypothesis 1}

The first hypothesis examines the effect of convenience on emotion, where the null hypothesis (Ho) and the alternative hypothesis (Ha) are as follows:

Ho1: Convenience has no positive effect on emotion in the use of m-commerce.

$\mathrm{Ha1}$ : Convenience has a positive influence on deep emotion in the use of $\mathrm{m}$-commerce.

Table 5 shows that the p-value on the first hypothesis is 0.000 <alpha 0.05 . Thus, H01 is rejected and Ha1 fails to be rejected. The coefficient of 0.205 shows the positive direction between the two variables. This means the greater the convenience, the higher the emotion. The results of this study are consistent with the results of previous studies conducted by Gupta and Kim (2007), which suggest that great convenience means that users can spend less time and effort to get more utility during use. In other words, high comfort has an impact on positive emotions. Enjoying a longer m-commerce service with little effort is one of the real-life examples that exist in everyday life.

Hypothesis 2

The next hypothesis examines the effect of self-efficacy on emotion, where the null hypothesis (Ho) and the alternative hypothesis (Ha) are as follows:

H02: Self efficacy has no positive effect on emotion in m-commerce use.

$\mathrm{Ha} 2$ : Self-efficacy has a positive influence on emotion in m-commerce use

Table 5 shows that the p-value for the this hypothesis is $0.000<$ alpha 0.05 , thus $\mathrm{H} 02$ is rejected and $\mathrm{Ha} 2$ fails to be rejected. The coefficient of 0.427 shows a positive direction between the two variables, which means the greater the self-efficacy, the higher the emotion. The results of this study are consistent with previous research results that demonstrate the belief that a person can achieve a goal and is believed to affect a person's mindset generating an emotional reaction, especially regulating emotions when experiencing a threatening or difficult situation (Bandura, 1997).

Hypothesis 3 
The next hypothesis examines the effect of emotion on the consumption experience, where the null hypothesis (Ho) and the alternative hypothesis (Ha) are as follows:

H03: Emotion has no positive effect on consumption experience.

Ha3: Emotion has a positive influence on the consumption experience.

Table 5 shows that the p-value for this hypothesis is $0.000<$ alpha 0.05 ; thus $\mathrm{H} 03$ is rejected and Ha3 is accepted. The coefficient of 0.959 shows a positive direction between the two variables. This means that the greater the emotion, the higher the consumption experience. The results of this study are consistent with the results of previous studies proposed by Wakefield and Whitten (2006) that suggested that high emotions, such as happiness, encourage a positive attitude that leads to ongoing use of $\mathrm{m}$-commerce.

Online shop service providers need complete information to conducting a product sale through m-commerce to show interest in the convenience variable. Customer may understand better about the information obtained from service providers. For self-efficacy variables, marketing managers need to standardize their online web shops so users can use and understand the entire m-commerce experience. For emotion variables, managers need to know what customers want and need because each customer has different characteristics; consequently, managers need to conduct surveys of consumers' behavior on the current trends of product desires. Lastly, the variable of consumption experience must be examined by the marketing manager to increase the loyalty of service providers to customers. One approach to that that can be used is by providing vouchers and gift for customers which buy product with certain amount of price. The goal is to give a positive impression to customers in the experience of consuming products and services provided by service providers.

M-commerce offers great flexibility of time and place. However, users may feel frustrated to adapt with the Internet by many factors, including their mobile devices, the telecom networks, and the application of $\mathrm{m}$ commerce itself. Mobile devices can save time, effort, and bring high comfort. To satisfy a customer you need to maintain good communication with them; therefore, it is advisable to add rich information, such as drawings, expressions and images, refine convenient input methods and develop the infrastructure such as expanding wireless networks.

\section{Conclusion}

Convenience has a positive effect on emotion in m-commerce use because convenience is one of the most important factors in the success of m-commerce. Users' convenience depends on every service provided by the service provider. Customers feel more comfort when using m-commerce services because it requires little effort and time. Thus, emotions will rise on their own when they feel satisfying comfort. Self-efficacy has a positive influence on emotion in $\mathrm{m}$-commerce use. Some feel that they can use $\mathrm{m}$-commerce if they have mastered similar technology before. So, there is positive emotion in feeling digital savvy and succeeding in using of $\mathrm{m}$ commerce.

Emotion has a positive influence on the consumption experience. Emotion refers to a feeling arising from experience in consuming a product or service. A happy, joyful, uninterrupted feeling is a positive emotion shown by m-commerce users. Therefore, if positive emotions are expended in conducting a service, it can encourage the experience of $\mathrm{m}$-commerce users in a sustainable manner. Thus, it can be concluded that research contributes to academic knowledge of the effect of the convenience, and self-efficacy on the emotion-mediated consumption experience.

\section{References}

Bandura, A. (1997). "Self-efficacy", Harvard Mental Health Letter, Vol. 13 No. 9, pp. 4-6.

Baron, Robert A dan Donn Byrne (2004). Psikologi Sosial. Alih bahasa Ratna Djuwita. Ed. 10, Jil. 1. Jakarta: Erlangga.

Berry, L.L. (1979). The time-buying consumer. Journal of Retailing, 55(4), 58-69.

Berry, L.L., Seiders, K., \& Grewal, D. (2002). Understanding service convenience. The Journal of Marketing, 66(3), 1-17.

Choi, J., Seol, H., Lee, S., Cho, H., \& Park, Y. (2008). Customer satisfaction factors of mobile commerce in Korea, Internet Research, 18(3), 313-35.

Codeluppi, V. (2000). Lo spettacolo della merce: I luoghi del consumo dai passages a Disney World. Milano, Bompiani.

Dabholkar, P.A., Bobbitt, L.M., \& Lee, E-J. (2003). Understanding consumer motivation and behavior related to selfscanning in retailing: Implications for strategy and research on technology-based self-service, International Journal of Service Industry Management, 14(1), 59-95.

Dickinger, A., Arami, M., \& Meyer, D. (2008). The role of perceived enjoyment and social norm in the adoption of technology with network externalities, European Journal of Information Systems, 17, 4-11.

Donovan, R.J., \& Rossiter, J.R. (1982). Store atmosphere: An environmental psychology approach, Journal of Retailing, 58(1), 34-57.

Eroglu, S.A., Machleit, K.A., \& Davis, L.M. (2001). Atmospheric qualities of online retailing: A conceptual model and implications, Journal of Business Research, 54(2), 77-84.

Eroglu, S.A., Machleit, K.A., \& Davis, L.M. (2003). Empirical testing of a model of online store atmospherics and shopper responses, Psychology \& Marketing, 20(2), 139-50. 
Forlizzi, J., \& Battarbee, K. (2004). Understanding experience in interactive systems. In: Proceedings of DIS 2004. A ' CM, 261-268.

Gross, B.L. (1987). Time scarcity: interdisciplinary perspectives and implications for consumer behavior, in Sheth, J.N. and Hirschman, E.C. (Eds), Research in Consumer Behavior, Vol. 3, JAI Press, Greenwich, CT, pp. 1-54.

Gupta, S., \& Kim, H.-W. (2007). The moderating effect of transaction experience on the decision calculus in on-line repurchase, International Journal of Electronic Commerce, 12(1), 127-58.

Hair, J.F.J., Anderson, R.E., Tatham, R.L., \& Black, W.C. (1998). Multivariate Data Analysis, 5th edition, Upper Saddle River: Prentice Hall.

Haytko, D \& Baker, J. (2004). It's all about at the mall: Exploring adolescent girls experience, Journal of Retailing, 80(1), 67-83.

Hermawan, Asep. 2009. Penelitian Bisnis Paradigma Kuantitatif. Grasiondo.

Hoffman, D.L., \& Novak, T.P. (1996). Marketing in hypermedia computer mediated environments: Conceptual foundations, Journal of Marketing, 60, 50-68.

Holbrook, M.B., \& Hirschman, E.C. (1982b). The experiential aspects of consumption: consumer fantasies, feeling, and fun, Journal of Consumer Research, 9, 132-40.

Hung, S.-Y., \& Chang, C.M. (2005). User acceptance of WAP services: Test of competing theories, Computer Standards \& Interfaces, 27(4), 359-70.

Jones, M.A. (1999). Entertaining Shopping Experiences: An Exploratory Investigation. J. Retail. Consum. Serv., 6, 129-139.

Keaveney, S (1995). Customer Switching Behavior in Service Industries: An Axploratory Study, Journal of Marketing, 59 (April), 71-82.

Kim, C., Mirusmonov, M., \& Lee, I. (2010). An empirical examination of factors influencing the intention to use mobile payment, Computer in Human Behavior, 26(3), 310-22.

Kleijnen, M., Ruyter, K., \& Wetzels, M. (2007). An assessment of value creation in mobile service delivery and the moderating role of time consciousness, Journal of Retailing, 83(1), 33-46.

Ko, E., Kim, E.-Y., \& Lee, E.K. (2009). Modeling consumer adoption of mobile shopping for fashion products in Korea, Psychology \& Marketing, 26(7), 669-87.

Li, Y.-M. \& Yeh, Y.-S. (2010). Increasing trust in mobile commerce through design aesthetics, Computers in Human Behavior, 26(4), 673-84.

Lovelock, C. (2001). Services Marketing: People, Technology, Strategy, 4th ed., Prentice-Hall, Upper Saddle River, NJ.

Lu, J., Liu, C., Yu, C.-S., \& Wang, K. (2008). Determinants of accepting wireless mobile data services in China, Information \& Management, $45,52-64$

Luarn, P., \& Lin, H.H. (2005). Toward an understanding of the behavioral intention to use mobile banking, Computers in Human Behavior, 21(6), 873-91.

Min, L., \& Dong, Z.Y. (2011). Factors influencing consumption experience of mobile commerce: A study from an experiental view, Journal of Management Science and Engineering, 22(2), 120-141.

Nazir, M. (2003). Metode Penelitian. Jakarta: Ghalia Indonesia.

O'Brien, H.L. (2010). The influence of hedonic and utilitarian motivations on user engagement: The case of online shopping experiences, Interacting with Computer, 22(5), 344-452.

Rainer, R.K., \& Cegielski, C.G. Introduction to Information Systems: Supporting and Transforming Business. Hoboken, New Jersey: John Willey \& Sons, 2007. p. 224-229.

Ratneshwar, S., Mick, D., \& Huffman, C. (2000). The Why of Consumption: Contemporary Perspectives on Consumer Motives, Goals and Desires. New York: Routledge.

Reichheld, F., \& Teal, T. (1996). The Loyalty Effect. Boston: Bain \& Company.

Schultz, D.P., \& Schultz, S.E. (1994). Psychology and Work Today: An Introduction to Industrial and Organizational Psychology (6th Ed.). New York: MacMillan Publishing Company.

Seiders, K., Berry, L.L., \& Gresham, L.G. (2000). Attention, retailers! How convenient is your convenience strategy?, Sloan Management Review, 41, 79-89.

Sugiyono. (2005). Memahami Penelitian Kualitatif. Bandung: Alfabeta.

Turban, E., David K., Jae L., \& dan, D. V. (2004). Electronic Commerce: A Managerial Perspective. Prentince Hall., USA.

Turel, O., Serenko, A., \& Bontis, N. (2010). User acceptance of hedonic digital artifacts: A theory of consumption values perspective, Information \& Management, 47(1), 53-9.

Verhoef, P.C., Lemon, K.N., Parasuraman, A., Roggeveen, A., Tsiros, M., \& Schlesinger, L.A. (2009). Customer Experience Creation: Determinants, Dynamics and Management Strategies. J. Retail., 85(1), 31-41.

Xu, G., \& Gutierrez, J.A. (2006). An exploratory study of killer applications and critical success factors in M-commerce, Journal of Electronic Commerce in Organizations, 4(3), 63-79. 